\title{
Effect of margin strips on soil mineral nitrogen and plant biodiversity
}

\author{
Benny De CAUWER ${ }^{\mathrm{a}}$, Dirk ReHEUL ${ }^{\mathrm{a}}$, Ivan NiJS ${ }^{\mathrm{b}}$, Ann MilBaU $^{\mathrm{b}}$ \\ ${ }^{a}$ Department of Plant Production, Faculty of Bioscience Engineering, Ghent University, Coupure Links 653, 9000 Ghent, Belgium \\ ${ }^{\mathrm{b}}$ Research Group of Plant and Vegetation Ecology, Department of Biology, University of Antwerp, Universiteitsplein 1, 2610 Wilrijk, Belgium
}

(Accepted 21 February 2006)

\begin{abstract}
We studied the effects of two- to three-year-old unfertilized field margin strips, installed between the pre-existing field boundary and the field crop, on soil ammonium $\mathrm{N}$ and nitrate $\mathrm{N}$, and on the botanical composition of the adjacent semi-natural vegetation in the field boundary. Margin plots were regenerated spontaneously or were sown to grass/forb mixtures and were managed under a cutting regime with removal of cuttings. In general, soil nitrate $\mathrm{N}$, soil ammonium $\mathrm{N}$ and soil mineral $\mathrm{N}$ losses were significantly affected by distance from the field crop edge and not by plant community type. The further away from the crop edge, the lower soil nitrate (up to fivefold lower than in the crop) was found in the margin strip, but soil ammonium $\mathrm{N}$ was approximately $50 \%$ higher close to nearby trees and shrubs. Inside the margin strip, total soil mineral $\mathrm{N}$ as well as $\mathrm{N}$ loss during winter was minimal at a distance of $5 \mathrm{~m}$ from the crop edge. The reduction of soil nitrate $\mathrm{N}$ near the boundary by the presence of a margin strip was responsible for the increase in abundance of less competitive species and for an up to $20 \%$ higher species-richness within the field boundaries. In summary, our results show clearly that margin strips both decrease $\mathrm{N}$ pollution of groundwater and increase botanical diversity. A minimal margin width of $5 \mathrm{~m}$ is recommended.
\end{abstract}

buffer strip / boundary / species diversity / nitrogen loss / nitrate / ammonium

\section{INTRODUCTION}

Arable field boundaries play an important role in the agricultural landscape since they provide a habitat for a range of perennial plant species as well as food, shelter and movement corridors between habitats for a multitude of animal species (Kleijn, 1997). However, botanical diversity in semi-natural pre-existing boundaries has declined considerably in recent decades (Bunce et al., 1994) mainly due to disturbances caused by modern agricultural activities on adjacent arable fields such as close ploughing, misplacement of fertilizer or drift of herbicides (Hald, 2002). According to Rew et al. (1992) and Tsiouris and Marshall (1998), who studied the patterns of granular fertilizer deposition beside field margins, fertilizer misplacement is likely to occur using spinning disk applicators, the commonest type of fertilizer applicator used on farms: pneumatic applicators would reduce off-field contamination. Regular fertilizer addition in field margins is likely to encourage nitrophilous species to dominate field margin communities and have adverse effects on their botanical diversity (Boatman et al., 1994). The remaining plant species are associated with eutrophic and productive biotopes (Hald, 2002). Weed problems in boundary strips are worsened by herbicide drift or herbicide use in ditch banks or hedge bottoms (de Snoo and de Wit, 1993) favoring strong rhizomatous species.

Sown or unsown nature conservation strips installed between an arable crop and pre-existing boundary may buffer flora in the pre-existing boundary, as shown by many authors (Hegarty et al., 1994; Moonen and Marshall, 2001; Hald, 2002). Margin strips may reduce nitrate leaching to surface waters (Hefting, 2003) or function as a filter preventing runoff of sediments and agrochemicals from reaching nearby habitats with susceptible or vulnerable organisms such as ditches or nature reserves (Mander et al., 1997; Verchot et al., 1997). Apart from the combined effect of direct $\mathrm{N}$ uptake and $\mathrm{N}$ incorporation (immobilization) in litter, buffer strip vegetation has a significant indirect role in $\mathrm{N}$ removal by stimulating denitrification activity through the supply of organic matter by litter and root exudates (Hefting, 2003). However, information is not abundant concerning mineral $\mathrm{N}$ rates and losses in soil horizons under field margin strips during winter months, or concerning the optimal width of field margin strips for reducing mineral $\mathrm{N}$ content in soil. Most studies mainly deal with forested buffer strips (Haycock and Pinay, 1993; Schultz et al., 1995; Mander et al., 1997; Verchot et al., 1997). Grass strips were found to reduce soil nitrate nitrogen concentrations by approximately $50 \%$ (Verchot et al., 1997). Nor are there many data about the optimal dimensions of margin strips to function as a buffer against drift of agrochemicals. Tsiouris and Marshall (1998) recommended a margin width of $5 \mathrm{~m}$ to protect adjacent boundary vegetation against drift of granular fertilizers deposited by disk spinners. According to Marrs et al. (1989), a strip of 6 m offered a very safe distance for preventing lethal effects from

\footnotetext{
* Corresponding author: Dirk.Reheul@Ugent.be
} 
herbicides sprayed by a tractor-mounted sprayer; for most herbicides 2-m-wide strips were sufficient.

Over the long term the reduction of agrochemical drift and soil nitrogen content in the boundary might benefit the development of a species-rich less nitrophilous vegetation, thus reducing costs of maintenance of the boundary.

Our study examines the effects of 2-3-year-old sown and unsown grassy margin strips between the boundary and the arable crop on soil mineral $\mathrm{N}$ content and loss during winter at two locations. In particular, the following questions are addressed: (1) Can sown/unsown grassy margin strips bordering arable crops reduce mineral $\mathrm{N}$ residues and loss during winter? (2) Is mineral $\mathrm{N}$ content and loss affected by plant community type or location? (3) Which margin width is recommended to minimize soil mineral $\mathrm{N}$ content and loss near the pre-existing boundary? (4) Is species richness and botanical composition of the semi-natural vegetation in the boundary positively affected by the presence of the margin strip?

\section{MATERIALS AND METHODS}

In June 2001 a field margin experiment was established on nutrient-rich arable land in a split-plot design with four plant communities (main plot), three mowing regimes (subplot) and three blocks. The plant communities were randomized within the blocks and the mowing regimes were randomized within the plant communities. The split-plot design was installed on two contrasting soil types in Belgium, in the province of West Flanders; namely, in Poperinge (SITE1: $50^{\circ} 52^{\prime} \mathrm{N}, 2^{\circ} 45^{\prime} \mathrm{E}$, drained sandy loam, $\mathrm{pH}-\mathrm{KCl} 6.8,1.5 \% \mathrm{C}$ ) and in Beernem (SITE2: $51^{\circ}$ $09^{\prime} \mathrm{N}, 3^{\circ} 20^{\prime} \mathrm{E}$, humid sandy soil, $\mathrm{pH}-\mathrm{KCl} 5.7,3.3 \% \mathrm{C}$ ). Analysis of the topsoil $(0-30 \mathrm{~cm})$ (June 2001) of SITE1 showed that extractable $\mathrm{P}$ and $\mathrm{K}$ were $27 \mathrm{mg}$ per $100 \mathrm{~g}$ soil and $31 \mathrm{mg}$ per $100 \mathrm{~g}$ soil, respectively, and total mineral $\mathrm{N}$ was $43 \mathrm{~kg} \cdot \mathrm{ha}^{-1}$. Analysis of the topsoil $(0-30 \mathrm{~cm})$ of SITE2 showed that extractable $\mathrm{P}$ and $\mathrm{K}$ were $75 \mathrm{mg}$ per $100 \mathrm{~g}$ soil and $31 \mathrm{mg}$ per $100 \mathrm{~g}$ soil, respectively, and total mineral $\mathrm{N}$ was $113 \mathrm{~kg} \cdot \mathrm{ha}^{-1}$. The experimental sites $(360 \times 20 \mathrm{~m}$ at SITE1 and $360 \times 10 \mathrm{~m}$ at SITE2) were ploughed with 7-month-old Italian ryegrass in May 2001 and divided into 36 plots $(10 \times 20 \mathrm{~m}$ at SITE1 and $10 \times 10 \mathrm{~m}$ at SITE2) arranged along an east-west-oriented watercourse at SITE1 and an east-west-oriented tree row along a ditch at SITE2. The pre-existing semi-natural boundary (hereafter called field boundary), encompassing the barrier between fields, constituted a watercourse bank with an irregular pattern of shrubs, pollarded trees and young trees at SITE1 and a small ditch bank along a tree row of 50-year-old oaks at SITE2. The experiments were conducted on a conventional farm at SITE1 and on an organic farm at SITE2. So, no agrochemicals were used in the adjacent crops at SITE2.

Apart from an unsown spontaneously evolving plant community (CONTR.), three different sown communities (MIXT1, MIXT2 and MIXT3; mixtures sown in June 2001) were studied (Tab. I). MIXT1 was established with a seed mixture of 63 species comprising native seeds of local provenance, and for MIXT2 a commercially-available seed mixture of 77 species comprising species completely unrelated to the sowing region was used. The initial composition of MIXT3 was identical to that of MIXT2 but once a year, seed-rich herbage originating from neighboring roadsides was added in order to enhance species diversity. Roadsides were cut around the end of September. Plant species in MIXT1 and MIXT2 were selected from a wide range of vegetation types: annual and perennial forbs from dry to moist grassland and perennial forbs thriving in nutrient-rich soils.

In the installation year, 2001, the field margin plots were cut once on 15 September with removal of the cuttings. During the subsequent years (2002, 2003 and 2004) the experimental plots were cut twice per year with cuttings either left or removed, resulting in three different mowing regimes: REMOV0, no removal of cuttings; REMOV1, removal of first cutting; REMOV2, removal of both cuttings. The cutting height was $5 \mathrm{~cm}$. To allow the seed set of a major proportion of the species and to allow the establishment of young seedlings, the first mowing date was postponed until 15 June (first cut). The vegetation was mown a second time around 15 September (regrowth cut).

At SITE1, the semi-natural vegetation in the field boundary was mown twice a year without removal of cuttings. At SITE2, it was mown once a year with removal of cuttings due to the reduced vegetation growth under the tree row. Vegetation succession in the field margin occurred under zero fertilization and no herbicide and pesticide use. For both sites, adjacent crops and their fertilizer, herbicide, fungicide and insecticide inputs are shown in Table II. At SITE1, ammonium nitrate and muriate of potash were spread by a tractor-mounted spinning disk spreader (Twindisk LELY, spinner was set for 9-m spread each side) with the tractor $9 \mathrm{~m}$ from the field margin edge. Pig slurry was applied by shank-type liquid manure injectors behind a tractor-pulled tanker. Soluble $\mathrm{N}$ was applied by a tractormounted sprayer boom. At SITE2, organic granules, vinasse, hair meal and blood meal were spread by a VICON oscillating spout spreader set for 6-m spread each side with the tractor $6 \mathrm{~m}$ from the field margin edge. Farmyard manure and farmyard compost (composted farmyard manure) were spread by a rearbeater spreader.

\subsection{Assessment}

During both the winter periods 2002-2003 and 2003-2004, mineral $\mathrm{N}$ content at SITE1 and SITE2 was determined in the REMOV2 plots. Soil samples were taken from three soil horizons: 0-30, 30-60 and 60-90 cm. Mineral N analysis was performed on soil samples taken at the end of the growing season (29 October 2002, 29 October 2003) and before the start of the next growing season (25 February 2003, 1 March 2004) using half-cylindrical augers of 4,3 and $2 \mathrm{~cm}$ diameter for the horizon 0-30, 30-60 and 60-90 cm, respectively. Soil augering was performed at fixed augering positions along nine transects perpendicularly centered on the MIXT1, MIXT2 and CONTR plots managed under REMOV2. For the winter period of 2002-2003 the augering positions at each site were: one in the field crop area $10 \mathrm{~m}$ away from the field margin edge (position $10 \mathrm{~m}$ ), one right at the border between the field margin and the crop (position $0 \mathrm{~m}$ ) and three positions in the margin strip; SITE1: 5, 10 and $20 \mathrm{~m}$ away from the crop edge (positions $-5,-10$ and $-20 \mathrm{~m}$, respectively); SITE2: 5, 7.5 and $10 \mathrm{~m}$ away from the crop edge (positions $-5,-7.5$ and $-10 \mathrm{~m}$, respectively). The outermost positions (position $-20 \mathrm{~m}$ at SITE1 and position 
Table I. Sown seed mixtures: composition, dose of native (MIXT1) and commercial (MIXT2) seed mixture. MIXT3 is identical to MIXT2.

\begin{tabular}{|c|c|c|c|c|c|c|}
\hline \multirow[t]{2}{*}{ Functional group } & \multicolumn{3}{|r|}{ MIXT1 } & \multicolumn{3}{|r|}{ MIXT2 } \\
\hline & $\begin{array}{l}\text { Dose } \\
\mathrm{g} \mathrm{ha}^{-1}\end{array}$ & $\mathrm{~N}^{1}$ & Origin & $\begin{array}{l}\text { Dose } \\
\mathrm{g} \mathrm{ha}^{-1}\end{array}$ & $\mathrm{~N}^{1}$ & Origin \\
\hline Non-nitrogen-fixing dicots & 6560 & 45 & Pleijboza (NL) & 5000 & 59 & Barenbrug (NL) \\
\hline native wildflowers & 6560 & 45 & & & & \\
\hline commercial wildflowers & & & & 5000 & 59 & \\
\hline Legumes & 9200 & 6 & & 9200 & 6 & \\
\hline Medicago sativa & 1800 & & Feldsaaten Freudenberger $(G)$ & 1800 & & Feldsaaten Freudenberger \\
\hline Trifolium incarnatum & 1500 & & Feldsaaten Freudenberger & 1500 & & Feldsaaten Freudenberger \\
\hline Trifolium pratense & 2000 & & CLO-DvP ${ }^{2}(\mathrm{~B})$ & 2000 & & Barenbrug \\
\hline Trifolium repens & 1400 & & CLO-DvP & 1400 & & Barenbrug \\
\hline Trifolium resupinatum & 1500 & & Feldsaaten Freudenberger & 1500 & & Feldsaaten Freudenberger \\
\hline Vicia sativa & 1000 & & Pleijboza & 1000 & & Feldsaaten Freudenberger \\
\hline Monocots & 26500 & 12 & & 26500 & 12 & \\
\hline Agrostis tenuis & 2000 & & collected $^{3}$ & 2000 & & Barenbrug \\
\hline Anthoxanthum odoratum & 600 & & Pleijboza & 600 & & Feldsaaten Freudenberger \\
\hline Arrhenatherum elatius & 3000 & & Pleijboza & 3000 & & Feldsaaten Freudenberger \\
\hline Cynosurus cristatus & 1200 & & Pleijboza & 1200 & & Feldsaaten Freudenberger \\
\hline Festuca arundinacea & 3600 & & collected & 3600 & & Barenbrug \\
\hline Festuca pratensis & 3000 & & CLO-DvP & 3000 & & Barenbrug \\
\hline Festuca rubra & 5000 & & CLO-DvP & 5000 & & Barenbrug \\
\hline Holcus lanatus & 1000 & & Pleijboza & 1000 & & Feldsaaten Freudenberger \\
\hline Lolium perenne & 3000 & & CLO-DvP & 3000 & & Barenbrug \\
\hline Phleum pratense & 1400 & & CLO-DvP & 1400 & & Barenbrug \\
\hline Poa trivialis & 700 & & collected & 700 & & Barenbrug \\
\hline Dactylis glomerata & 2000 & & collected & 2000 & & Barenbrug \\
\hline
\end{tabular}

${ }^{1} \mathrm{~N}=$ number of species (spp.).

${ }^{2}$ CLO-DvP: Department of Plant Genetics and Breeding, Agricultural Research Center, Merelbeke (Belgium).

${ }^{3}$ Collected in the neighborhood of the trials.

$-10 \mathrm{~m}$ at SITE2) were taken at the edge of the field boundary. For the winter period 2003-2004 augering positions were concentrated more at the border of the field crop area. Augering positions for both sites were: one position in the field crop area (position $2.5 \mathrm{~m}$ ), one position right at the border between the field margin and the crop (position $0 \mathrm{~m}$ ) and four positions in the margin strip (positions $-1.25,-2.5,-5$ and $-7.5 \mathrm{~m}: 1.25,2.5$, 5 and $7.5 \mathrm{~m}$, respectively, from the crop edge). At each augering position three spots (at the center and $2 \mathrm{~m}$ right and left perpendicular to the augering transect) were augered. Per augering position samples were mixed for each horizon separately. Mixed samples were immediately deep-frozen prior to determination of nitrate $\mathrm{N}\left(\mathrm{NO}_{3}-\mathrm{N}\right)$ and ammonium $\mathrm{N}\left(\mathrm{NH}_{4}-\mathrm{N}\right)$ using continuous flow spectroscopy performed on oven-dried soil. Nitrate $\mathrm{N}$ was determined according to the cadmium reduction method (ISO/DIS 14256-1, ISO/DIS 13395). Nitrate is reduced to nitrite using cadmium as the reducing agent. The resulting nitrite concentration is then determined colorimetrically. Ammonium $\mathrm{N}$ was determined according to the salicylate method (ISO/DIS 14256-1, ISO/DIS 11732): free ammonia reacts with hypochlorite to form monochloramine; monochloramine then reacts with salicylate, in the presence of sodium nitro-ferricyanide, to form 5-aminosalicylate, a green colored complex. Amounts $\left(\mathrm{kg} \cdot \mathrm{ha}^{-1}\right)$ of soil $\mathrm{NO}_{3}-\mathrm{N}$ and $\mathrm{NH}_{4}-\mathrm{N}$ in each soil horizon were calculated by multiplying the laboratory contents (mg N. $\mathrm{kg}^{-1}$ oven-dried soil) with the specific apparent gravity of the soil and volume of the soil within the relevant horizon. Mineral nitrogen $\left(\mathrm{Nmin}, \mathrm{kg} \cdot \mathrm{ha}^{-1}\right.$ ) in each soil horizon was calculated by adding amounts of $\mathrm{NO}_{3}-\mathrm{N}$ and $\mathrm{NH}_{4}-\mathrm{N}$. Amounts of $\mathrm{Nmin}_{2} \mathrm{NO}_{3}-\mathrm{N}$ and $\mathrm{NH}_{4}-\mathrm{N}$ in the soil horizon $0_{-}$ $90 \mathrm{~cm}$ (hereafter called total $\mathrm{Nmin}$, total $\mathrm{NO}_{3}-\mathrm{N}$ and total $\mathrm{NH}_{4}-$ $\mathrm{N}$, respectively) were calculated by adding individual amounts in each soil horizon.

Over each winter period Nmin loss $\left(\mathrm{kg} \mathrm{N} \cdot \mathrm{ha}^{-1}\right)$ during winter was calculated as a net $\mathrm{N}$ change by subtracting the residual Nmin at the end of October from Nmin at the end of February of the next year. This calculation does not take into account airborne $\mathrm{N}$ deposition and mineralization/immobilization between the autumn and spring sampling occasions. 


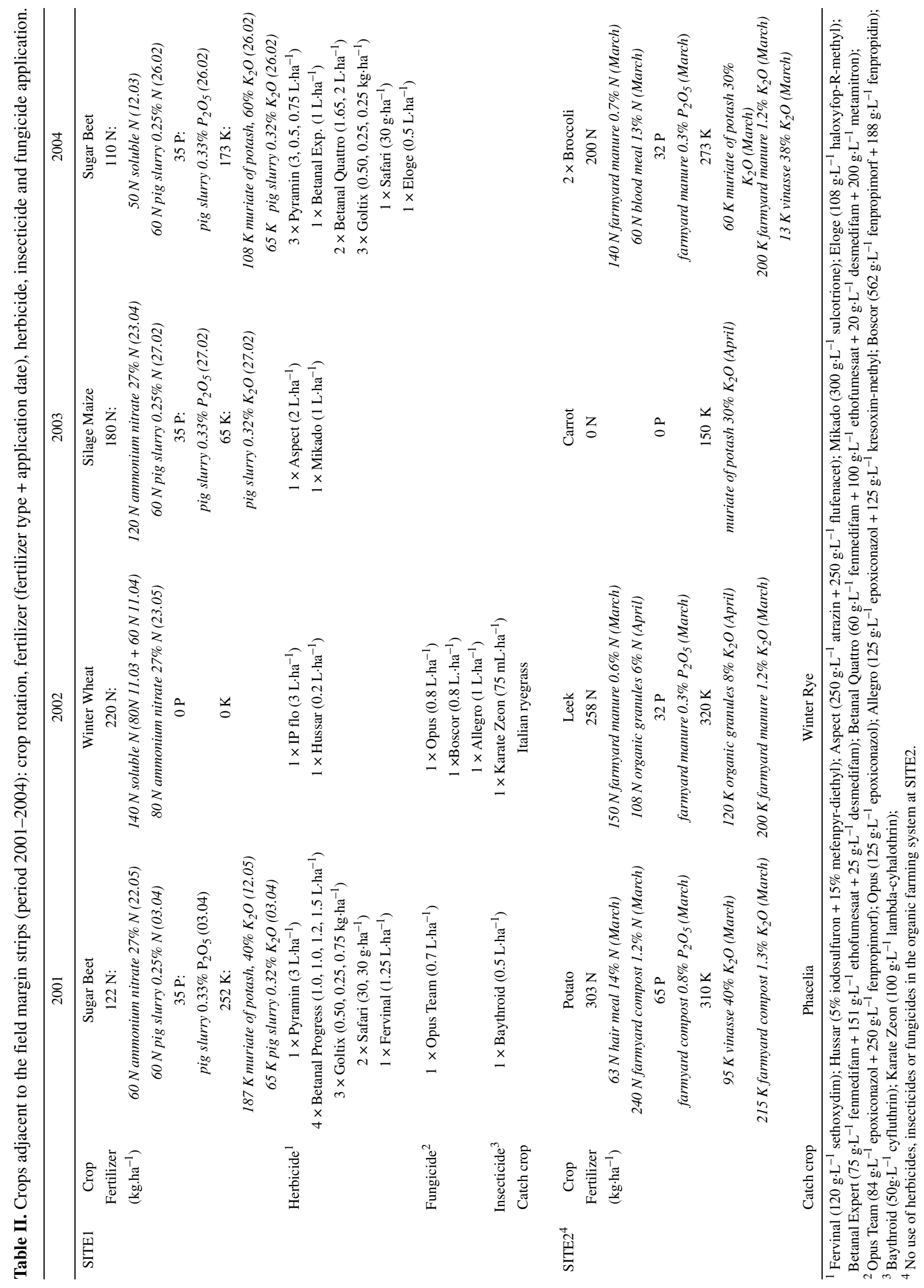


Residual Nmin after the growing season (i.e. Nmin amount at the end of October) was compared with the Flemish legislative limit: according to this legal prescription no more than $90 \mathrm{~kg} \mathrm{NO}{ }_{3}-\mathrm{N} \cdot \mathrm{ha}^{-1}$ should be present in the soil horizon up to $90 \mathrm{~cm}$ of depth. This level was established in order not to exceed the maximum concentration of $50 \mathrm{mg}$ nitrate $\cdot \mathrm{L}^{-1}$ or $11.3 \mathrm{mg}$ $\mathrm{N} \cdot \mathrm{L}^{-1}$ in surface and groundwater as stipulated in the European Nitrate Directive (Anonymous, 1991).

During the period 2002-2004, the botanical composition of the vegetation was recorded yearly on 15 July, thirty days after the mid-June cut. Species occurrence was recorded within the central $4 \times 4 \mathrm{~m}$ area of each $10 \times 10 \mathrm{~m}$ plot. Species importance was derived from the presence in sixteen randomly-placed quadrats $(13 \times 13 \mathrm{~cm})$ within the central $4 \times 4 \mathrm{~m}$ area of each plot according to the combined frequency-rank method of De Vries (De Vries and de Boer, 1959). Species presence was expressed in terms of percentage of importance (I\%) based on the ranking of biomass contributed by the various plant species within each quadrat. The botanical composition in terms of importance of functional groups was recorded over time by calculating the percentile contribution of three functional groups to the total importance $(=100 \%)$. Species were classified into the following functional groups: legumes (LEG), non-N-fixing dicotyledons (DIC) and monocotyledons (MON). The I\% of a functional group was calculated by adding the I\% of all contributing species of that group.

Boundary flora was studied to investigate the likely ecological effects of the presence of a margin strip on the adjacent field boundary. The composition of the flora of the field boundary was measured prior to installation (2001) and yearly in June during the period 2002-2004, on a Tansley (1954) scale ( $\mathrm{r}=$ rare $; \mathrm{o}=$ occasional; $\mathrm{f}=$ frequent $\mathrm{a}=$ abundant $\mathrm{d}=$ dominant $)$.

ANOVA (SPSS10 for Windows) was used for statistical calculations of $\mathrm{Nmin}_{2} \mathrm{NO}_{3}-\mathrm{N}$ and $\mathrm{NH}_{4}-\mathrm{N}$ amounts and $\mathrm{I} \%$ of functional groups for plant communities (MIXT1, MIXT2 and CONTR) under REMOV2. In this report the factor mowing regime of the installed split-plot design was not studied since soil augering and Nmin analysis was solely performed on all REMOV2 plots of MIXT1, MIXT2 and CONTR. So, the splitplot design was analyzed as a complete block design. Since soil augering positions and adjacent crops and fertilizer applications differed between locations during both winter periods, statistical analysis was performed per location according to a two-factor experiment (plant community and augering position) in a complete block design with random block effect. The I\% of functional groups was analyzed according to a two-factor experiment (plant community and location) in a complete block design with random block effect.

\section{RESULTS AND DISCUSSION}

\subsection{Soil Nmin analysis}

\section{Winter 2002-2003}

The distribution of residual total $\mathrm{Nmin} \mathrm{NH}_{4}-\mathrm{N}$ and $\mathrm{NO}_{3}-\mathrm{N}$ as analyzed in samples taken on 29 October 2002 at SITE2 are

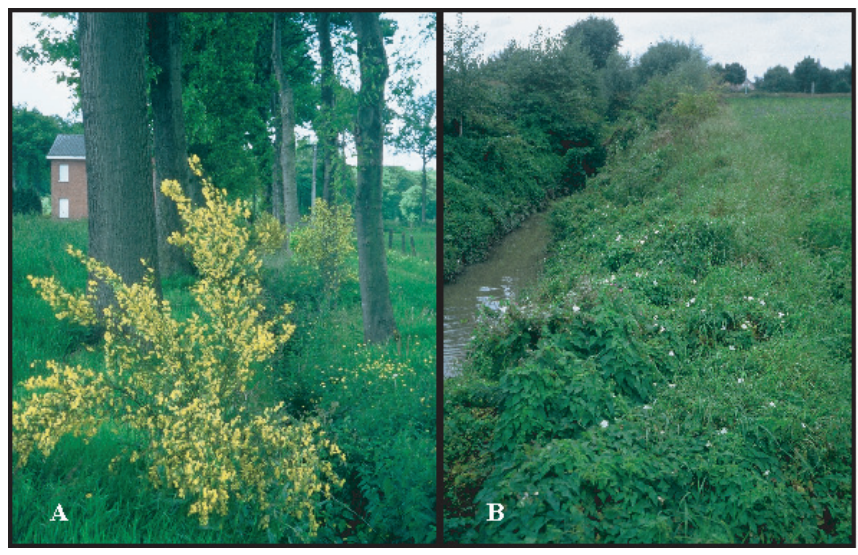

Figure 1. Pre-existing field boundaries: species-rich ditch bank (A); species-poor nitrophilous ditch bank (B).

shown in Figure 1. Data were averaged over the plant communities and are presented for the different soil horizons.

Given that the $\mathrm{NH}_{4}-\mathrm{N}$ data show limited trends and that most of the variation in total $\mathrm{Nmin}$ arises from variations in $\mathrm{NO}_{3}-\mathrm{N}$, residual total Nmin was not further statistically analyzed. Augering position significantly determined total $\mathrm{NH}_{4}-\mathrm{N}$ (Tab. III) at SITE2 but not at SITE1 at the end of October 2002. Contrary to total $\mathrm{NO}_{3}-\mathrm{N}$, total $\mathrm{NH}_{4}-\mathrm{N}$ in the crop area was not significantly higher than $\mathrm{NH}_{4}-\mathrm{N}$ in the field margin strip, irrespective of location. However, atSITE2, total $\mathrm{NH}_{4}-\mathrm{N}$ was significantly higher at position $-10 \mathrm{~m}$ than at any other position. Within the field margin strip at SITE2, total $\mathrm{NH}_{4}-\mathrm{N}$ exceeded total $\mathrm{NO}_{3}-\mathrm{N}$ : the closer the field boundary, the more $\mathrm{NH}_{4}-\mathrm{N}$.

Focusing on residual total $\mathrm{NO}_{3}-\mathrm{N}$ at the end of October 2002 (Tab. III), the Flemish legal threshold value of $90 \mathrm{~kg} \mathrm{NO}_{3^{-}}$ $\mathrm{N} \cdot \mathrm{ha}^{-1}$ was exceeded in the field crop area but not in the margin strip at SITE2. At SITE1 no more than $90 \mathrm{~kg} \mathrm{NO}-\mathrm{N} \cdot \mathrm{ha}^{-1}$ in the horizon 0-90 cm was found, irrespective of augering position. Total $\mathrm{NO}_{3}-\mathrm{N}$ at SITE2 was only significantly determined by augering position, with significantly higher total $\mathrm{NO}_{3}-\mathrm{N}$ in the crop area than in the field margin strip. Within the field margin strip total $\mathrm{NO}_{3}-\mathrm{N}$ decreased from position $0 \mathrm{~m}$ up to position $-10 \mathrm{~m}$. Similar results were found at SITE1 but differences were not significant. Total $\mathrm{NO}_{3}-\mathrm{N}$ at SITE2 were twofold higher than $\mathrm{NO}_{3}-\mathrm{N}$ at SITE1, irrespective of augering position.

Compared with the residual total $\mathrm{NH}_{4}-\mathrm{N}$ at the end of October 2002, total $\mathrm{NH}_{4}-\mathrm{N}$ was higher at the end of February 2003, irrespective of augering position or location. Again, position $-10 \mathrm{~m}$ at SITE2 showed a significantly higher total $\mathrm{NH}_{4}-\mathrm{N}$ than all other positions. At SITE2 total $\mathrm{NO}_{3}-\mathrm{N}$ showed no significant differences between augering positions. At SITE1, position $10 \mathrm{~m}$ showed significantly higher $\mathrm{NO}_{3}-\mathrm{N}$ compared with other positions due to the early slurry application.

Nmin loss over the winter period 2002-2003 was significantly determined by augering position, irrespective of location. At SITE2, a significant Nmin loss occurred under the crop area but we monitored a soil Nmin accrual in the field margin strip. At SITE1 no Nmin losses were found, irrespective of augering position. 
Table III. Soil $\mathrm{NH}_{4}-\mathrm{N}$ and $\mathrm{NO}_{3}-\mathrm{N}\left(\mathrm{kg} \mathrm{N}_{\mathrm{h}} \mathrm{ha}^{-1}\right)$ on 29 October 2002 and on 25 February 2003, and Nmin loss $\left(\mathrm{kg} \mathrm{N} \cdot \mathrm{ha}^{-1}\right)$ during winter 20022003 along transects perpendicular to margin strips. (Abbreviations cf. p. 5).

\begin{tabular}{|c|c|c|c|c|c|c|c|c|c|c|c|}
\hline \multirow{3}{*}{$\mathrm{COM}^{1}$} & \multirow{3}{*}{$\operatorname{POS}^{1}$} & \multicolumn{5}{|c|}{ SITE1 } & \multicolumn{5}{|c|}{ SITE2 } \\
\hline & & \multicolumn{2}{|c|}{29 October 2002} & \multicolumn{2}{|c|}{25 February 2003} & \multirow[t]{2}{*}{$\mathrm{N} \operatorname{loss}^{2}$} & \multicolumn{2}{|c|}{29 October 2002} & \multicolumn{2}{|c|}{25 February 2003} & \multirow{2}{*}{$\mathrm{N} \operatorname{loss}^{2}$} \\
\hline & & $\mathrm{NH}_{4}-\mathrm{N}$ & $\mathrm{NO}_{3}-\mathrm{N}$ & $\mathrm{NH}_{4}-\mathrm{N}$ & $\mathrm{NO}_{3}-\mathrm{N}$ & & $\mathrm{NH}_{4}-\mathrm{N}$ & $\mathrm{NO}_{3}-\mathrm{N}$ & $\mathrm{NH}_{4}-\mathrm{N}$ & $\mathrm{NO}_{3}-\mathrm{N}$ & \\
\hline \multicolumn{12}{|l|}{ Mean } \\
\hline & -20 & 27.2 & 39.8 & 57.1 & 60.8 & -50.8 & 116.0 & 32.8 & 160.3 & 43.9 & -55.5 \\
\hline & -10 & 31.7 & 46.0 & 47.6 & 47.7 & -17.6 & 83.7 & 46.9 & 102.5 & 43.1 & -15.0 \\
\hline & -5 & 33.9 & 41.9 & 52.4 & 42.0 & -18.6 & 84.6 & 49.8 & 101.2 & 46.4 & -13.3 \\
\hline & 0 & 34.9 & 44.3 & 58.1 & 51.7 & -30.6 & 99.8 & 102.5 & 108.7 & 45.7 & 48.0 \\
\hline & 10 & 35.1 & 62.8 & 79.8 & 93.0 & -75.0 & 78.7 & 143.9 & 93.2 & 47.5 & 81.9 \\
\hline \multicolumn{12}{|c|}{ Anova $(\mathrm{LSD})^{3}$ : } \\
\hline \multicolumn{2}{|l|}{$\mathrm{COM}$} & NS & NS & NS & NS & NS & NS & NS & NS & NS & NS \\
\hline \multirow{2}{*}{\multicolumn{2}{|c|}{ POS }} & NS & NS & NS & $* * *$ & $* *$ & $* *$ & $* * *$ & $* *$ & NS & $*$ \\
\hline & & & & & $(22.4)$ & (31.8) & $(18.1)$ & $(52.4)$ & $(32.9)$ & & $(84.1)$ \\
\hline \multicolumn{2}{|c|}{$\mathrm{COM} \times \mathrm{POS}$} & NS & NS & NS & NS & NS & NS & NS & NS & NS & NS \\
\hline
\end{tabular}

${ }^{1} \mathrm{COM}$, plant community; POS, augering positions: $-20,-10$ and $-5 \mathrm{~m}$ within the margin strip, 0 right at the border; between margin strip and crop, 10: $10 \mathrm{~m}$ within the crop.

${ }^{2} \mathrm{~N}$ loss $=$ Nmin on 29 October $-\mathrm{Nmin}$ on 25 February.

${ }^{3}$ Significance: NS, not significant; $*=P<0.05 ; * *=P<0.01 ; * * *=P<0.001$. LSD, least significant difference $(P<0.05)$ according to Fisher LSD test.

\section{Winter period $2003-2004$}

The distribution of residual total Nmin, $\mathrm{NH}_{4}-\mathrm{N}$ and $\mathrm{NO}_{3}-\mathrm{N}$ (averaged over plant communities) over the different soil horizons at SITE2 are shown in Figure 2. At the end of the growing season, residual Nmin in the soil horizon 0-90 cm in the crop area was high at SITE2 owing to the high organic C content in the soil. The installation of a field margin strip, separating the field boundary and the crop area, decreased residual Nmin significantly close to the field boundary. This reduction occurred mainly in the deeper soil horizons 30-60 and 60-90 cm which are more prone to mineral leaching. In the field crop area, Nmin in the horizon 30-90 cm was sixfold higher than Nmin at position $-5 \mathrm{~m}$ in the margin strip. Half of the total $\mathrm{NH}_{4}-\mathrm{N}$ was found in the uppermost horizon, irrespective of position. Total $\mathrm{NO}_{3}$ $\mathrm{N}$ steadily decreased from position $2.5 \mathrm{~m}$ up to $-5 \mathrm{~m}$. Contrary to positions inside the margin strip, approximately $70 \%$ of the total $\mathrm{NO}_{3}-\mathrm{N}$ in the field crop area was found in the deeper soil horizons, 30-60 and 60-90 cm. The reduction in $\mathrm{NO}_{3}-\mathrm{N}$ inside the margin strip was higher in the deeper soil horizons 30-60 and 60-90 cm than in the uppermost soil horizon. Similar but less pronounced, more flattened patterns were found at SITE1.

Given that the $\mathrm{NH}_{4}-\mathrm{N}$ data show limited trends and that most of the variation in total $\mathrm{Nmin}$ arises from variations in $\mathrm{NO}_{3}-\mathrm{N}$ (Fig. 3), residual total Nmin data was not further statistically analyzed in Table IV. Residual total $\mathrm{NH}_{4}-\mathrm{N}$ at the end of October 2003 was significantly determined by augering position at SITE2. No significant factors were found at SITE1. At SITE2, total $\mathrm{NH}_{4}-\mathrm{N}$ inside the margin strip increased with increasing distance away from the edge of the crop area. The closer to the tree lane, the higher the total $\mathrm{NH}_{4}-\mathrm{N}$. At SITE 1, total $\mathrm{NH}_{4}-\mathrm{N}$ was not affected by augering position. Contrary to $\mathrm{NO}_{3}-\mathrm{N}$, $\mathrm{NH}_{4}-\mathrm{N}$ in the margin strip at SITE2 increased with increasing

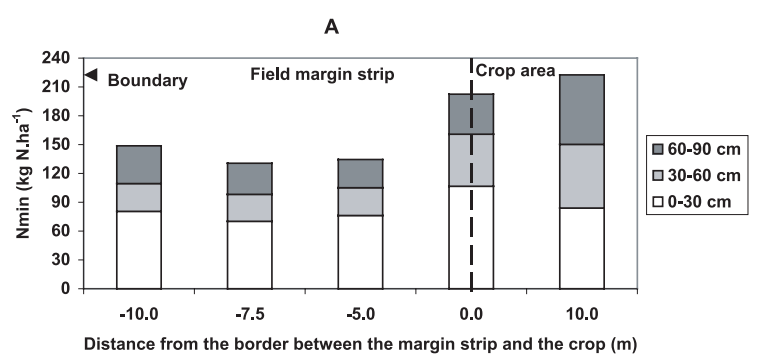

B

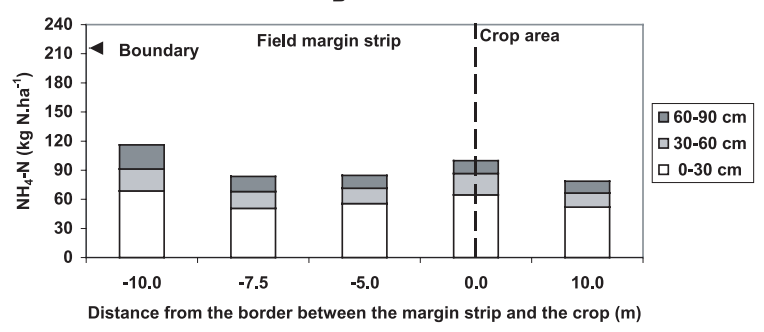

C

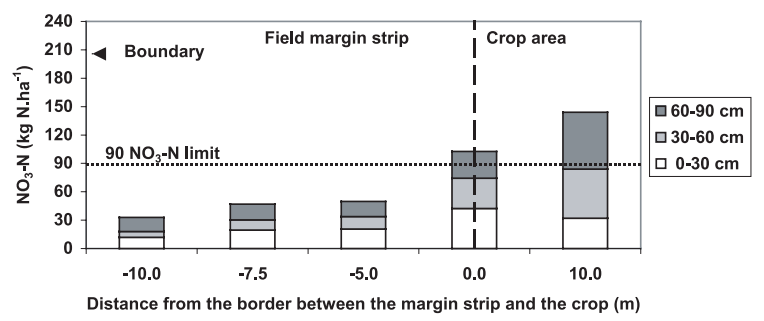

Figure 2. Distribution of total $\mathrm{Nmin}(\mathrm{A}), \mathrm{NH}_{4}-\mathrm{N}(\mathrm{B})$ and $\mathrm{NO}_{3}-\mathrm{N}(\mathrm{C})$ in soil horizons $0-30,30-60$ and $60-90 \mathrm{~cm}$ related to distance from the border between the margin strip and the crop. SITE2, 29 October 2002. 


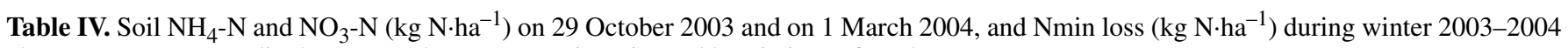
along transects perpendicular to sown/unsown margin strips (Abbreviations cf. p. 5).

\begin{tabular}{|c|c|c|c|c|c|c|c|c|c|c|c|}
\hline \multirow{3}{*}{$\mathrm{COM}^{1}$} & \multirow{3}{*}{$\mathrm{POS}^{1}$} & \multicolumn{5}{|c|}{ SITE1 } & \multicolumn{5}{|c|}{ SITE2 } \\
\hline & & \multicolumn{2}{|c|}{29 October 2003} & \multicolumn{2}{|c|}{1 March 2004} & \multirow{2}{*}{$\mathrm{N} \operatorname{loss}^{2}$} & \multicolumn{2}{|c|}{29 October 2003} & \multicolumn{2}{|c|}{1 March 2004} & \multirow{2}{*}{$\mathrm{N} \operatorname{loss}^{2}$} \\
\hline & & $\mathrm{NH}_{4}-\mathrm{N}$ & $\mathrm{NO}_{3}-\mathrm{N}$ & $\mathrm{NH}_{4}-\mathrm{N}$ & $\mathrm{NO}_{3}-\mathrm{N}$ & & $\mathrm{NH}_{4}-\mathrm{N}$ & $\mathrm{NO}_{3}-\mathrm{N}$ & $\mathrm{NH}_{4}-\mathrm{N}$ & $\mathrm{NO}_{3}-\mathrm{N}$ & \\
\hline \multicolumn{12}{|l|}{ Mean: } \\
\hline CONTR & & 29.9 & 82.3 & 38.2 & 46.1 & 27.8 & 61.1 & 120.1 & 61.6 & 46.2 & 73.6 \\
\hline MIXT1 & & 29.3 & 105.4 & 39.4 & 77.1 & 18.2 & 67.6 & 130.3 & 65.5 & 49.2 & 83.1 \\
\hline MIXT2 & & 28.4 & 72.0 & 42.8 & 48.0 & 9.6 & 62.6 & 131.8 & 58.2 & 52.9 & 83.3 \\
\hline & -7.5 & 29.6 & 62.8 & 38.9 & 40.8 & 12.7 & 71.0 & 61.7 & 76.3 & 30.1 & 26.4 \\
\hline & -5 & 30.5 & 62.8 & 42.5 & 36.6 & 14.2 & 69.4 & 52.0 & 63.1 & 25.5 & 32.9 \\
\hline & -2.5 & 31.1 & 63.3 & 41.2 & 35.9 & 17.3 & 70.0 & 61.0 & 60.9 & 26.8 & 43.3 \\
\hline & -1.25 & 29.3 & 67.5 & 41.1 & 37.6 & 18.1 & 62.9 & 78.0 & 60.4 & 43.1 & 37.5 \\
\hline & 0 & 30.8 & 80.0 & 42.3 & 76.2 & -7.7 & 58.2 & 199.5 & 57.2 & 88.0 & 112.5 \\
\hline & 2.5 & 23.9 & 183.0 & 34.6 & 115.5 & 56.9 & 51.1 & 312.2 & 52.8 & 83.1 & 227.4 \\
\hline \multicolumn{12}{|c|}{ Anova $(\mathrm{LSD})^{3}$ : } \\
\hline $\mathrm{COM}$ & & NS & $\begin{array}{c}* \\
(26.2)\end{array}$ & NS & $\begin{array}{c}* \\
(25.7)\end{array}$ & NS & NS & NS & NS & NS & NS \\
\hline POS & & NS & $\begin{array}{c}* * * \\
(37.1)\end{array}$ & NS & $\begin{array}{c}* * * \\
(36.3)\end{array}$ & NS & $\begin{array}{c}* * * \\
(10.9)\end{array}$ & $\begin{array}{c}* * * \\
(100.1)\end{array}$ & $\begin{array}{c}* * * \\
(11.8)\end{array}$ & $\begin{array}{c}* * * \\
(27.8)\end{array}$ & $\begin{array}{c}* * * \\
(95.3)\end{array}$ \\
\hline $\mathrm{COM} \times \mathrm{P}$ & & NS & NS & NS & NS & NS & NS & NS & NS & NS & NS \\
\hline
\end{tabular}

distance from the crop edge. This was attributable to the presence of a row of fifty-year-old oaks in the field boundary. Near tree rows soil $\mathrm{pH}$ is often low due to the acidifying effect of nitrification of leaf litter (Van Breemen et al., 1982). Consequently, during litter decomposition, the organic matter input near tree rows is mainly ammonified instead of nitrified under conditions of low $\mathrm{pH}$ since the activity of nitrifying bacteria is reduced at $\mathrm{pH}-\mathrm{KCl}$ below 6.0 (Fenchel et al., 1998). As a result, ammonium accumulates in the topsoil near the field boundary. Furthermore, nitrification may also be inhibited by tannins and phenolics under deciduous forest trees. So, aside from the adjacent crop area, soil Nmin in the field margin strips was also influenced by the semi-natural vegetation of the field boundary. The positively-charged ammonium ions are absorbed and fixed on the negatively-charged soil particles, thus avoiding leaching.

Residual total $\mathrm{NO}_{3}-\mathrm{N}$ at the end of October 2003 was significantly determined by augering position at SITE2 and by augering position and plant community at SITE1. At the end of the growing season, total $\mathrm{NO}_{3}-\mathrm{N}$ in the field margin strip never exceeded the Flemish legal threshold value of $90 \mathrm{~kg}$ residual $\mathrm{NO}_{3}-\mathrm{N} \cdot \mathrm{ha}^{-1}$ in the horizon $0-90 \mathrm{~cm}$, contrary to the field crop area. Similarly, Schultz et al. (1995) found in a multispecies riparian buffer strip along a stream in Iowa a reduction in $\mathrm{NO}_{3}-\mathrm{N}$ contents from $12 \mathrm{mg} \cdot \mathrm{L}^{-1}$ in an adjacent arable field to levels never exceeding $2 \mathrm{mg} \cdot \mathrm{L}^{-1}$ in the buffer strip. The reduced amounts of residual soil $\mathrm{NO}_{3}-\mathrm{N}$ under the margin strip might be attributed to zero fertilization, periodic removal of biomass, $\mathrm{N}$ immobilization in decomposing litter and denitri- fication in winter stimulated by the supply of organic matter by litter and root exudates (Hanson et al., 1994; Lyons et al., 2000; Hefting, 2003). At both sites, total $\mathrm{NO}_{3}-\mathrm{N}$ in the field margin strip decreased asymptotically from $0 \mathrm{~m}$ up to position $-7.5 \mathrm{~m}$ except for a slight increase at position $-7.5 \mathrm{~m}$ at SITE2. At SITE1, total $\mathrm{NO}_{3}-\mathrm{N}$ averaged over all positions perpendicular to MIXT1 was significantly higher than total $\mathrm{NO}_{3}-\mathrm{N}$ perpendicular to MIXT2. Generally, total $\mathrm{NO}_{3}-\mathrm{N}$ was higher at SITE2 than at SITE1, irrespective of augering position.

Total $\mathrm{NH}_{4}-\mathrm{N}$ on 1 March 2004 was not determined by augering position at SITE1, contrary to SITE2. At SITE2, total $\mathrm{NH}_{4-}$ $\mathrm{N}$ increased from the crop area to the edge of the field boundary.

On 1 March 2004, total $\mathrm{NO}_{3}-\mathrm{N}$ at both sites was significantly higher in the field crop area than inside the margin strip. In the margin strip total $\mathrm{NO}_{3}-\mathrm{N}$ decreased from position 0 to $-2.5 \mathrm{~m}$ and from position 0 to $-5 \mathrm{~m}$ for SITE1 and SITE2, respectively, and increased again closer to the field boundary. At SITE1, total $\mathrm{NO}_{3}-\mathrm{N}$ was significantly higher perpendicular to MIXT1 than perpendicular to CONTR and MIXT2. The patterns of total $\mathrm{NO}_{3}-\mathrm{N}$ followed at best the patterns of total Nmin.

Nmin loss over the winter period 2003-2004 was solely significantly determined by position at SITE2. No significant factors were found for Nmin loss at SITE1. Inside the field margin strip Nmin loss decreased with increasing distance from the edge of the field crop area. Nmin loss was minimal $7.5 \mathrm{~m}$ from the edge of the field crop, irrespective of location. Under the field crop area, extremely high Nmin losses were found, 


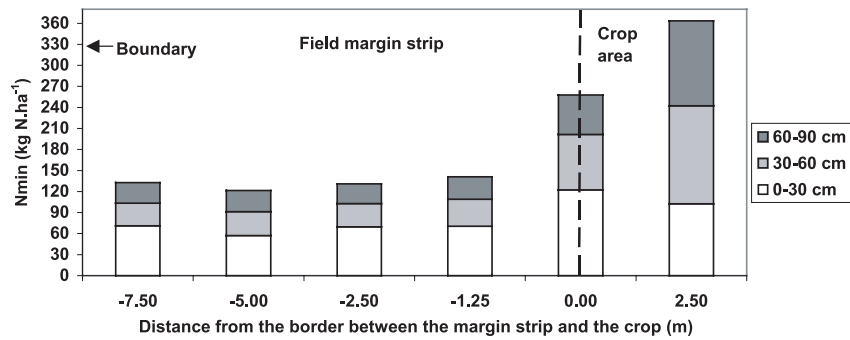

B

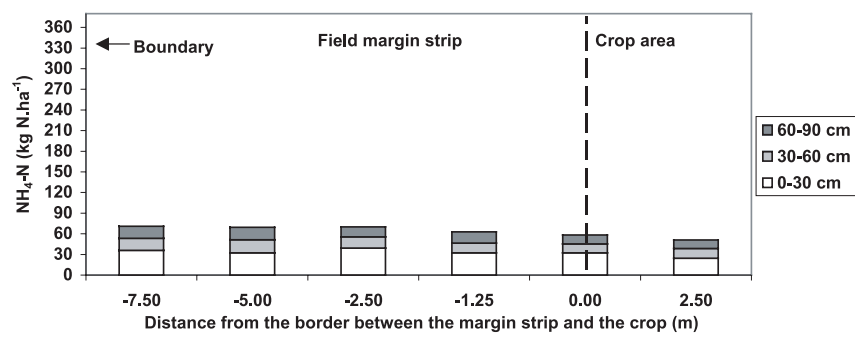

c

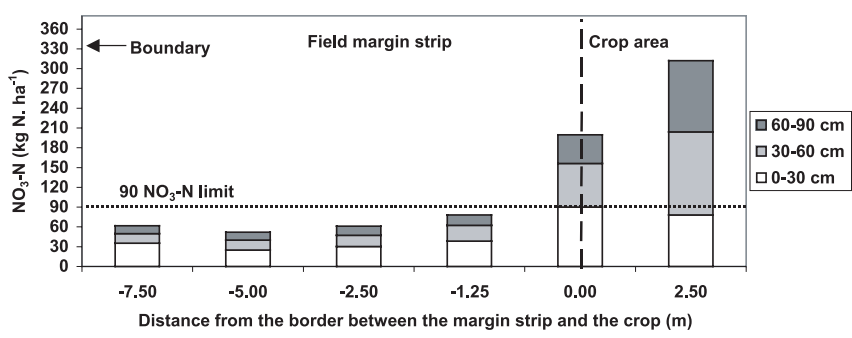

Figure 3. Distribution of total $\mathrm{Nmin}(\mathrm{A}), \mathrm{NH}_{4}-\mathrm{N}(\mathrm{B})$ and $\mathrm{NO}_{3}-\mathrm{N}(\mathrm{C})$ in soil horizons $0-30,30-60$ and $60-90 \mathrm{~cm}$ related to the distance from the border between the margin strip and the crop. SITE2, 29 October 2003.

particularly at SITE2. In the margin strips Nmin losses during winter were, if any, significantly lower than in the crop area. This is attributable to the lower amounts of residual Nmin and $\mathrm{NO}_{3}-\mathrm{N}$, particularly in the soil horizons $30-60$ and $60-90 \mathrm{~cm}$. So, a perennial vegetation at the edges of fields might reduce nitrogen leaching into watercourses. This is in agreement with Marrs et al. (1991) who demonstrated that rates of nitrogen loss were higher on arable soils left fallow than on arable land sown with perennial ryegrass or under grassland.

Field margin type did not significantly determine Nmin loss, despite the significantly higher residual $\mathrm{Nmin}$ and $\mathrm{NO}_{3}-\mathrm{N}$ under the clover-rich MIXT1 (at SITE1), as a result of symbiotic nitrogen fixation (results not shown). However, a major part of soil Nmin was found in the uppermost horizon where it is less prone to leaching. Our installed field margin types showed only small differences in mineral nitrogen. These small differences will presumably not increase during further succession since vegetation compositions of sown/unsown plant communities become increasingly look-alike over time (De Cauwer et al., 2005). Hence, $\mathrm{N}$ export in the removed biomass will be comparable over time owing to the converging biomass production of sown/unsown plant communities over time and similar $\mathrm{N}$ contents of the harvested produce, which is also indicated by Lyons et al. (2000) and Sabater et al. (2003), who found no significant difference in $\mathrm{N}$ removal between vegetation types. However, $\mathrm{N}$ removal by the periodic removal of biomass ( $\mathrm{N}$ uptake) and $\mathrm{N}$ immobilization might be higher in younger vegetations than in older vegetations, irrespective of location. $\mathrm{N}$ immobilization might be higher during the first successional years as a result of the relatively rapid and marked increase in soil organic matter stimulating microbial populations which tie up much of the soil nitrogen in an unavailable form (Garwood et al., 1977). Owing to the accumulation of organic matter in the rooting zone and the repeated removal of the cuttings, the high-yielding sown species are expected to be replaced by species with a less abundant nutrient consumption such as Agrostis spp. and Festuca spp.

Taking into account the asymptotically decreasing pattern of $\mathrm{Nmin}$ and $\mathrm{NO}_{3}-\mathrm{N}$, a field margin of $5 \mathrm{~m}$ width sufficiently reduced soil Nmin and Nmin losses. At greater width no extra reduction in soil Nmin or Nmin loss occurred. A margin width of $5 \mathrm{~m}$ corresponds with the margin widths recommended by Marrs et al. (1989), de Snoo and de Wit (1993) and Tsiouris and Marshall (1998) for drift of herbicides, pesticides and granular fertilizers (deposited by disk spinners), respectively. However, for waterlogged margin strips adjacent to water streams, wider margins might be preferred to increase subsurface removal of nitrates by denitrification.

\subsection{Botanical analysis}

Table V shows mean I\% and annual I\% of functional groups for all installed margin strip vegetations during the succession period 2002-2004. The mean I\% of legumes (average I\% over the period 2002-2004) was significantly determined by location and plant community. SITE1 revealed a significantly and twofold higher mean I\% than SITE2. Compared with SITE2, SITE1 revealed a significantly lower mean I\% of monocotyledons and non-leguminous dicotyledons and significantly higher mean I\% of legumes than SITE2. MIXT1 revealed a significantly higher mean I\% of legumes and lower mean I\% of monocotyledons than MIXT2 and CONTR. CONTR showed a significantly higher mean I\% of non-leguminous dicotyledons than sown communities, showing no significant difference.

Species richness and the composition of boundary vegetation evolved positively after installation of a margin strip between the field boundary and field crop. At SITE2, three years after installation of the margin strip, the botanical species diversity of the field boundary was higher compared with the species diversity prior to installation (49 spp. in 2004 versus 42 spp. in 2001). Slow-growing non-nitrophilous species such as Geranium molle, Stellaria graminea, Veronica chamaedrys, Viola arvensis, Cerastium fontanum and Hypericum dubium and more particularly, leguminous species such as Ornithopus perpusillus, Medicago lupulina and Vicia hirsuta did not occur prior to installation of the margin strip but were present after installation. None of these species originated from the sowing mixtures of the margin strip. Aside from changes in species composition, changes in species abundance also occurred over 
Table V. Annual and mean importance (I\%) of functional groups for sown/unsown plant communities at two locations under REMOV2 (Abbreviations cf. p. 5).

\begin{tabular}{|c|c|c|c|c|c|c|c|c|c|c|c|c|c|}
\hline \multirow{3}{*}{$\operatorname{LOC}^{1}$} & \multirow[b]{3}{*}{$\mathrm{COM}^{1}$} & \multicolumn{12}{|c|}{ Functional group } \\
\hline & & \multicolumn{4}{|c|}{ Non-leguminous dicotyledons } & \multicolumn{4}{|c|}{ Legumes } & \multicolumn{4}{|c|}{ Monocotyledons } \\
\hline & & 2002 & 2003 & 2004 & Mean & 2002 & 2003 & 2004 & Mean & 2002 & 2003 & 2004 & Mean \\
\hline \multicolumn{14}{|l|}{ Mean } \\
\hline SITE1 & & 25.7 & 9.9 & 9.1 & 14.9 & 41.0 & 36.4 & 31.3 & 36.2 & 33.3 & 53.8 & 59.6 & 48.9 \\
\hline \multirow[t]{5}{*}{ SITE2 } & & 29.1 & 22.9 & 17.8 & 23.3 & 23.0 & 11.2 & 11.4 & 15.2 & 47.9 & 65.9 & 70.8 & 61.5 \\
\hline & MIXT1 & 18.8 & 14.4 & 16.4 & 16.6 & 45.1 & 31.3 & 29.5 & 35.3 & 36.1 & 54.2 & 54.1 & 48.1 \\
\hline & MIXT2 & 17.0 & 9.9 & 6.9 & 11.3 & 40.1 & 23.4 & 18.0 & 27.2 & 42.9 & 66.7 & 75.1 & 61.6 \\
\hline & MIXT3 & 19.6 & 17.0 & 13.8 & 16.8 & 39.9 & 26.7 & 23.7 & 30.1 & 40.5 & 56.3 & 62.5 & 53.1 \\
\hline & CONTR & 54.2 & 24.3 & 16.8 & 31.8 & 3.0 & 13.5 & 14.2 & 10.2 & 42.8 & 62.2 & 69.0 & 58.0 \\
\hline \multicolumn{14}{|c|}{ Anova $(\mathrm{LSD})^{2}$ : } \\
\hline \multirow[t]{2}{*}{ LOC } & & NS & $* * *$ & $*$ & $* *$ & $* * *$ & $* * *$ & $* * *$ & $* * *$ & $* *$ & $* *$ & $*$ & $* * *$ \\
\hline & & & 4.7 & 7.7 & 4.8 & 5.5 & 7.7 & 7.2 & 3.8 & 8.5 & 6.5 & 10.2 & 5.8 \\
\hline \multirow[t]{2}{*}{ COM } & & $* *$ & $* *$ & NS & $* * *$ & $* * *$ & $*$ & $*$ & $* * *$ & NS & $*$ & $*$ & $*$ \\
\hline & & 10.8 & 6.6 & & 6.8 & 7.7 & 10.8 & 10.2 & 5.4 & & 9.2 & 14.5 & 8.2 \\
\hline \multirow{2}{*}{\multicolumn{2}{|c|}{$\mathrm{LOC} \times \mathrm{COM}$}} & $*$ & NS & NS & NS & $* *$ & NS & NS & NS & NS & NS & NS & NS \\
\hline & & 15.3 & & & & 10.9 & & & & & & & \\
\hline
\end{tabular}

${ }^{1}$ LOC, location; COM, plant community.

${ }^{2}$ Significance: NS, not significant; $*=P<0.05 ; * *=P<0.01 ; * * *=P<0.001$. LSD, least significant difference $(P<0.05)$.

the 4-year period. Some species preferring low soil fertility such as Calluna vulgaris, Anthoxanthum odoratum, Rumex acetosella, Festuca rubra and Cytisus scoparius already present prior to installation became more abundant after installation. Over the 4-year period the abundance of nitrophilous species such as Urtica dioica, Rumex obtusifolius and Rubus idaeus was not greatly affected. Due to the presence of a tree row (50-year-old oaks) and a small ditch, boundary vegetation comprised plant species from dry (such as Teucrium scorodonia, Cytisus scoparius, Jasione montana, etc.) to moist (such as Polygonum amphibium, Juncus effusus, Galium palustre, etc.) habitats and forbs thriving in nutrient-poor (such as Anthoxanthum odoratum, Ornithopus perpusillus, Calluna vulgaris, etc.) to nutrient-rich (such as Urtica dioica, Rumex obtusifolius, Elymus repens, etc.) soils. Owing to the organic farm management we are sure that the beneficial evolution in species diversity and composition was not due to a buffering effect for agrochemicals of the margin strip. So, species richness and abundance of less competitive species was increased directly owing to the reduction of nutrient input from the adjacent arable field. Marshall and Moonen (1998) and Tsiouris and Marshall (1998) demonstrated the competitive growth of nitrophilous species in fertile soils, limiting the development of slower-growing species. So, an impoverished adjacent margin strip might offer better opportunities for slow-growing species to develop in the field boundary. Aside from the reduction of fertilizer drift, the presence of a margin strip might eliminate root foraging by tall competitive species, thus discouraging nitrophilous species. Tall dominant plant species such as Urtica dioica were found to actively adjust root and shoot growth into locally resource-rich zones such as edges with arable crops while low-growing species rather depended on capturing pulses of resources in nutrient-poor environments more efficiently (Campbell et al., 1991; Kleijn, 1997).

The species richness of the field boundary at SITE1 remained stable over the period 2001-2004 with 46 species prior to installation and 47 species three years after installation of the field margin strip. The boundary vegetation was highly nitrophilous with high abundance of Arrhenatherum elatius, Urtica dioica, Heracleum spp., Calystegia sepium, Galium aparine and Rumex obtusifolius. Indicator species from moist conditions such as Arctium minus, Bidens tripartita, Heracleum mantegazzianum, Symphytium officinale and Scrophularia auriculata were present. No clear changes in species composition or abundance occurred over the 4-year period. Nevertheless, some wildflower species such as Hypericum perforatum, Torilis japonica and Scrophularia auriculata absent prior to installation were found three years after installation. At SITE1 the timescale of the experiment was probably too short to discourage the highly nitrophilous vegetation growing on this heavy soil type. Also, Boatman et al. (1994) found no major changes in species composition of hedge banks fertilized over a 3-year period. 


\section{CONCLUSION}

Our results show that field margin strips, separating a field boundary and field crop, offer opportunities to buffer the seminatural vegetation in the field boundary and watercourses against cropped areas loaded with high levels of mineral nitrogen. The semi-natural vegetation became less competitive and species-richer by the presence of a margin strip. In the long term, the presence of a margin strip between the crop edge and the field boundary might restore the semi-natural vegetation in the field boundary, creating a non-nitrophilous, weed-free and species-rich plant community. This might result in lower costs for maintenance of boundary vegetation. Margin strips reduced the mineral nitrogen content of the soil and mineral nitrogen loss during winter months. The field margin type showed only small effects on mineral N. Mineral nitrogen loss was not affected by field margin type but by distance from the field crop. So, designing margin strips to reduce $\mathrm{N}$ input in watercourses should predominantly focus on the factor width than on the factor plant community type. A minimal width of $5 \mathrm{~m}$ is necessary to reach an optimal reduction in mineral soil $\mathrm{N}$ and $\mathrm{N}$ losses.

Acknowledgements: This research was supported by the Federal Office for Scientific, Technical and Cultural Affairs (Prime Minister's Office, Brussels, Belgium), under the program Global Change, Ecosystems and Biodiversity.

\section{REFERENCES}

Anonymous (1991) Council Directive of 12 December 1991 concerning the protection of water against pollution caused by nitrates from agricultural sources (91/676/EEC), Official J. Eur. Comm. L375, $1-8$.

Boatman N.D., Rew L.J., Theaker A.J., Froud-Williams R.J. (1994) The impact of nitrogen fertilisers on field margin flora, in: Boatman N.D. (Ed.), Field Margins: Integrating Agriculture and Conservation, BCPC Monograph No. 58, Thornton Heath, Surrey, UK, British Crop Protection Council, pp. 209-214.

Bunce R.G.H., Howard D.C., Barr C.J., Cummins R.C., French D. (1994) Botanical diversity in British hedgerows, in: Boatman N.D. (Ed.), Field Margins: Integrating Agriculture and Conservation, BCPC Monograph No. 58, Farnham, Surrey, UK, pp. 43-52.

Campbell B.D., Grime J.P., Mackey J.M.L. (1991) A trade-off between scale and precision in resource foraging, Oecologia 87, 532-538.

De Cauwer B., Reheul D., D’hooghe K., Nijs I., Milbau A. (2005) Evolution of the vegetation of mown field margins over their first three years, Agr. Ecosyst. Environ. 109, 87-96.

de Snoo G.R., de Wit P.J. (1993) Pesticide drift from knapsack sprayers to ditches and ditch banks, Proceedings of the 1993 Brighton Crop Protection Council, Farnham, Surrey, UK.

De Vries D.M., de Boer Th.A. (1959) Methods used in botanical grassland research in the Netherlands and their application, Herbage Abstracts 29, 1-7.

Fenchel T., King G.M., Blachburn R.H. (1998) (Eds.) Bacterial Biogeochemistry: the Ecophysiology of Mineral Cycling, San Diego, Academic Press, 307 p.

Garwood E.A., Tyson K.C., Clement C.R. (1977) A comparison of yield and soil conditions during 20 years of grazed grass and arable cropping, Hurley: Grassland Research Institute, Technical Report No. 21.
Hald A.B. (2002) Impact of agricultural fields on vegetation of stream border ecotones in Denmark, Agr. Ecosyst. Environ. 89, 127-135.

Hanson G.C., Groffman P.M., Gold A.J. (1994) Denitrification in riparian wetlands receiving high and low nitrate inputs, J. Environ. Qual. 23, 917-922.

Haycock N.E., Pinay G. (1993) Groundwater nitrate dynamics in grass and poplar vegetated riparian buffer strips during the winter, J. Environ. Qual. 22, 273-278.

Hefting M. (2003) Nitrogen Transformation and Retention in Riparian Buffer Zones, Ph.D. Thesis, Utrecht University, 200 p.

Hegarty C.A., McAdam J.H., Cooper A. (1994) Factors influencing the plant species composition of hedges - implications for management in Environmentally Sensitive Areas, in: Boatman N.D. (Ed.), Field Margins: Integrating Agriculture and Conservation, Monograph No. 58, British Crop Protection Council, pp. 227-234.

Kleijn D. (1997) Species Richness and Weed Abundance in the Vegetation of Arable Field Boundaries, Ph.D. Thesis, Wageningen Agricultural University, $176 \mathrm{p}$.

Knowles R. (1982) Denitrification, Microbial Review 46, 43-70.

Lyons J., Trimble S.W., Paine L.K. (2000) Grass versus trees: managing riparian areas to benefit streams of central North America, J. Am. Water Resour. Ass. 36, 919-930.

Mander U., Kuusemets V., Lohmus K., Mauring T. (1997) Efficiency and dimensioning of riparian buffer zones in agricultural catchments, Ecol. Eng. 8, 299-234.

Marrs R.H., Gough M.W., Griffiths M. (1991) Soil chemistry and leaching losses of nutrients from seminatural grassland and arable soils on 3 contrasting parent materials, Biol. Conserv. 57, 257-271.

Marrs R.H., Williams C.T., Frost A.J., Plant R.A. (1989) Assessment of the effects of herbicide spray drift on a range of plant species of conservation interest, Environ. Pollut. 59, 71-86.

Marshall E.J.P., Moonen C. (1998) A review of field margin conservation strips in Europe, A Report for the UK Ministry of Agriculture, Fisheries and Food, IACR Long Ashton Research Station, Bristol, UK, $92 \mathrm{p}$.

Moonen A.C., Marshall E.J.P. (2001) The influence of sown margin strips, management and boundary structure on herbaceous field margin vegetation in two neighbouring farms in south England, Agr. Ecosyst. Environ. 86, 187-202.

Rew L.J., Theaker A.J., Froud-Williams R.J., Boatman N.D. (1992) Nitrogen fertilizer misplacement and field boundaries, Aspects Appl. Biol. 30, 203-206.

Sabater S., Butturini A., Clément J.C., Dowrick D., Hefting M.M., Maitre V., Pinay G., Postolache C., Rzepecki M., Sabater F. (2003) Nitrogen removal by riparian buffers under various $\mathrm{N}$ loads along an European climatic gradient: patterns and factors of variation, Ecosystems 6, 20-30.

Schultz R.C., Colletti J.P., Isenhart T.M., Simpkins W.W., Mize C.W., Thompson M.L. (1995) Design and placement of a multispecies riparian buffer strip system, Agroforest. Syst. 29, 201-226.

Tansley A.G. (1954) Introduction to plant ecology: a guide for beginners in the study of plant communities, Allen and Unwin, London, $263 \mathrm{p}$.

Tsiouris S., Marshall E.J.P. (1998) Observations on patterns of granular fertiliser deposition beside hedges and its likely effects on the botanical composition of field margins, Ann. Appl. Biol. 132, $115-127$.

Van Breemen N., Burrough P.A., Velthorst E.J., Van Dobben H.F., De Wit T., Ridder T.B., Reijnders H.F.R. (1982) Soil acidification from atmospheric ammonium sulfate in forest canopy throughfall, Nature 299, 548-550.

Verchot L.V., Franklin E.C., Gilliam J.W. (1997) Nitrogen cycling in piedmont vegetated filter zones 2 . Subsurface nitrate removal, J. Environ. Qual. 26, 337-347. 